\title{
A Case Study of STEM Professionals Who Chose Teaching as a Second Career
}

\author{
Sheila R. Vaidya ${ }^{1} \&$ Joji Thompson ${ }^{1}$ \\ ${ }^{1}$ School of Education, Drexel University, Philadelphia, PA, USA \\ Correspondence: Sheila R. Vaidya, School of Education, Drexel University, Philadelphia, PA, USA. E-mail: \\ vaidyasr@drexel.edu
}

Received: April 4, 2020

Accepted: July 2, $2020 \quad$ Online Published: October 29, 2020

doi:10.5539/ies.v13n11p108

URL: https://doi.org/10.5539/ies.v13n11p108

\begin{abstract}
There has been a growing increase in the numbers of STEM professionals who choose teaching as a second career for reasons such as dissatisfaction with their existing work situation, desire for life-work balance or a desire to make an impact. How do these teachers adjust to the teaching profession? What do they bring from their life and work experience? How effective are they as teachers? These are the questions that are being researched here with a group of 18 STEM career changers who enrolled in a post-baccalaureate program offered at an urban university in Philadelphia.
\end{abstract}

Keywords: STEM professionals, teaching, second career

\section{Introduction}

\subsection{The Problem}

A recent report from the Brookings Institute (Dee \& Goldhaber, 2017) provides data indicating that teacher shortages are not a national occurrence because shortages are limited to low- income schools and to subjects such as STEM and special education. The challenges of recruiting teachers for low- income high-need schools are longstanding, indicating that innovative approaches need to be designed to address them. Some Schools of Education have found solutions addressing shortages by designing state approved alternate certification programs for STEM professionals who want to change careers and choose teaching as a second career.

The National Science Foundation's Robert Noyce Scholarship program supports scholarships and stipends for STEM subjects to obtain teacher certification, requiring them to teach in a high-need school for two years for every $\$ 10,000$ scholarship or stipend provided to a prospective teacher. Those already possessing a baccalaureate or higher degree in a STEM area are given a stipend of $\$ 10,000$ to complete post- baccalaureate teacher certification with the stipulation that they would teach in a high needs school for a minimum of two years. As a major urban university that received a National Science Foundation grant, we have recruited 30 post-baccalaureate graduate students and followed them over a three -year period to study their transition into teaching.

The purpose of this research is to study how teachers who change careers to enter teaching, the second career teachers, how they experience teaching and what motivate them to enter teaching. Despite the national increase in the number of teachers in this "second career group" not much research has been conducted with second career teachers compared to the vast number of studies of first career and first career beginning teachers.

A review of the literature into making a career change into teaching indicates that social and personal factors are relevant influences in making the career change decision (Bauer, Thomas, \& Sim, 2017). Social factors include a changing economy, losing one's job, or changing location and being unable to find an alternative job in the same field. Personal factors include being dissatisfied with one's previous job, looking for a challenge, the desire to make a difference, having a long standing desire to be a teacher, desiring a sociable environment, wanting a work/life balance, perceiving a career fit based on personal ability and prior career and personal experience.

These findings are supported by work motivation theories (Waters \& Diezmann, 2015; Grier \& Johnston, 2009). In another study of motivations (Watt, Richardson, \& Pietsch, 2007) the findings indicated that teaching was seen as having job security and allowing for more time with family as compared with other jobs and these perceptions resulted in finding teaching as a second career an attractive choice. 
While career change into teaching has been a recurring phenomenon during the last twenty years or so, it is interesting to highlight notable research that describes the transition into teaching as consisting of several changes over time resulting in transformation as delineated in Mezirow's Transformative Learning theory. Mezirow's study examines the transformation (professional growth) of career-changing women scientists who decided to become teachers. Drawing upon Mezirow's Transformative Learning Theory, (Snyder, Oliviera, \& Paska, 2013) tracked a group of females who moved into teaching from their career as a scientist. The researchers tracked teacher transformation over three years revealing multiple identities, and negative emotions such as disorientation, a perceived sense of meaninglessness, loss. Overcoming these over time results in eventual regain in confidence, gain in pedagogical knowledge and skill, and changed perceptions of the social roles of science teachers and scientists. Driven by personal choice or need (financial or intellectual), such transformations were achieved through active pursuit of meaning in one's work, critical assessment of assumptions, planning, and trying on the unfamiliar role of a science teacher. It is argued that such transition entails complex changes in thinking about science teaching and identifying oneself as a science teacher. Thus, career changers developed a new way of making sense of "self" within a new frame of reference which is the "teaching frame of reference". They further add that the transformation requires a new "self" as a science teacher which also entails developing a new professional mindset.

Self-determination theory is built on the assumption that humans are intrinsically motivated towards learning, growth, and intellectual challenge. It suggests however, that this innate motivation requires support from the interpersonal environment in the workplace in order to remain motivated. Among the necessary support essentials are encouragement to be self- initiating and volitional. The theory also predicts that learning environments which support autonomy will enhance a person's intrinsic motivation, whereas environments that control behavior and thus diminish the sense of volition and choice will undermine this natural motivation.

The frameworks provided by the Transformation Learning theory (Mezirow, 1978) and the Self-determination theory (Deci and Ryan, 1991) allows us to study and interpret the issues pertaining to psychological processes entailed in the transitions and the intrinsic motivational factors that drive the work of effective career changers.

As career change teachers are hired and as they teach and contribute to student learning in school, it is important to know more about this group of teachers. The questions we studied are:

1) What is the nature and essence of the experiences of a group of second career teachers who make a transition into teaching in high-need schools?

2) What kinds of influences do second career beginning teachers' previous work experiences have on their current role as a teacher?

3) What factors influence the retention of career changers in teaching?

\subsection{Research Objectives}

i. To determine how second career teachers experience teaching

ii. To identify the influence of previous work experience on their role as a teacher.

iii. To establish factors that influences the role of career changers in teaching.

\section{Method}

A qualitative embedded multiple case study approach to data generation was adopted because it allows the researcher to focus on obtaining rich descriptions of contextual factors that impact experiences and to probe how and why questions (Yin, 2009). Invitations to participate in the study were distributed to all career changers who were enrolled in the University's post-baccalaureate certification program, especially designed for STEM area graduates who wished to obtain certification in Mathematics or in one of the sciences (Physics, Chemistry, Biology, Environmental Science, General Science). They had all received a \$10,000 scholarship towards their tuition as well as a $\$ 1,000$ towards a grant for classroom supplies, if they wrote a mini- grant proposal to the Robert Noyce Scholarship committee for classroom supplies.

\subsection{Participant (Subject) Characteristics}

The 18 teachers chosen to participate in the research study were all mature age individuals who had taught in a high-needs school for at least three years. They all had baccalaureate or Masters' level degrees in either Engineering, Mathematics or Science. They had all worked in a STEM career outside of teaching. Teachers who were chosen as the sample had to be teaching in a high needs school for at least three years.

The total sample consisted of eighteen subjects; nine females and nine males. Most (63\%) were in the age 
category of 31-40 years old. Of the remaining, three were in the age group of 41-50 and four were younger (21-30 age category). A substantial number (84\%) of the group had a baccalaureate or a Master's degree; a small minority $15 \%$ had a doctorate. The previous careers were engineering (10 participants); research lab work (3 participants) and one person had a background in computer science; the remaining 4 participants' previous careers were not known.

\subsection{Sampling Procedures}

A purposive sampling method was used to recruit participants/Program graduates who had been teaching for at least three years were recruited into the study. Teachers were contacted by email, phone, and text and asked to participate in a 45 to 60 -minute virtual meeting.

\subsection{Data Collection Method}

The qualitative interview (Kvale, 2006) was the tool used to capture teachers' lived classroom experiences.

In qualitative interviews, social scientists investigate varieties of human experience. There is an attempt to understand the world from the subjects' points of view and to unfold the meaning of their lived world. Qualitative interviews undoubtedly function effectively in many contexts. The one-to-one interview has

The interviews were audio recorded using the virtual meeting software, and then transcribed. The interview consisted of the following questions:

1) What made you want to change careers and pursue a career in education?

2) How did you go about seeking the transition into education?

3) How are you adjusting to the teaching profession?

4) What were some of the challenges you have faced inside the classroom?

5) What were some of the challenges you have faced outside the classroom?

6) What are some things you like about teaching compared to your previous profession?

7) What is your teaching philosophy?

8) How has your previous profession/education helped or hindered your work as a teacher?

9) What kinds of projects have you initiated in your class that are unique to your field of experience?

10) How has your previous profession/knowledge helped/hindered your teaching?

Teachers' responses were followed up by unscripted probes to elicit more information about experienced issues such as mentoring, first year experiences.

\subsection{Data Analysis}

Analysis was conducted through the process of open coding (Strauss \& Corbin, 2010; Saldana, 2016). To answer the research questions, transcribed data was qualitatively analyzed using codes to establish salient themes and ideas. A table was created with categories of themes and sub- themes emerging from responses to interview questions that were guided by the research questions in the study. To support validity, corroboration in the data analysis was sought from a peer reviewer who examined the data and the categories.

\section{Results}

The findings are grouped in categories beginning with teachers' reasons for entering teaching, their expectations from students, their experiences inside and outside the classroom and the degree to which they used their previous career experience to adjust to teaching.

i. Reasons for entering teaching: Interviews and surveys agree with the existing data with most reasons being given as of relational value-like to work with people instead of office/desk work; enjoy the social interactions with students; want to give back to society; want to work where there is a need such as in high need communities. Some have indicated having a long-time plan to teach and have waited to realize it at the right time. Below are excerpts of some comments.

It is rewarding to have a direct impact

Every day is different

It feels good to be a part of a community.

I enjoyed a past teaching career, enjoyed working with children I wanted to leave a boring career; 
Appreciation for a past teacher;

I am looking for a career with job stability;

Grew up in the Inner city and wanted to give back

ii. Teacher Expectations:

Teachers had high expectations from the students and believed that all students could learn and also that each student has a unique pace and style. They emphasized that students' abilities should never be under estimated. Furthermore, it is important to take an interest to "know" and understand the student once this "connection" happens one can teach them anything.

iii. Teachers' experiences inside and outside the school:

Positive Experiences: Experiencing Wonder in the classroom-Positive effect of teaching because one can see an immediate impact and transformation such as a "spark" from an understanding gained.

Likes to see contribution to someone's growth;

Love the relationships with students and a sense of appreciation.

I was proud to witness every student gain strides in their mathematical education and as a result I finally understood the statement "some students will learn despite their teacher but every student will truly learn because of their teacher". "The joy of seeing a child transform into the people they are meant to be.

iv. Adjustment to Teaching:

Half the group (9 teachers) described their adjustment to teaching "by drawing on prior experiences" This was a recurring theme among the nine teachers who described "using real-world examples to explain concepts in Physics and Mathematics. Or a mathematics teacher with engineering and accounting background uses real-life examples to teach concepts such as "depreciation", salaries and commission based projects.

Other example of using previous career experiences used in teaching consisted of a previous entrepreneur who was able to call on a network of local support financially and academically to support classroom projects on Aerospace Engineering which consisted of a mission to send a hamster to mars; A senior engineering project consisting of designing a solar powered pressure cooke for use in Madagascar.

v. Challenges experienced inside and outside the classroom:

The participants' greatest perceived challenges in their new career of teaching focused on students' academic apathy and poor preparation to learn new content, poor administrative leadership negative student behaviors including bad language used in the classroom and problems with classroom management, time management, and management of grading and paperwork. Additionally, a lack of support in the school, lack of classroom resources and supplies and a sense of isolation were experienced by most teachers. Others felt that they were experiencing a "backward step" in finances since schools do not value the previous background or work experience brought to the profession by second career teachers. They also shared negative experiences inside the classroom such as difficulties with student engagement, poor administrative leadership. Challenges outside the classroom that consistently emerged were lack of work-life balance; grading and lesson preparation taking away extensive time.

Despite these challenges, there were positive sides about going into teaching. Among the most often quoted were 'the joy of making an impact in the community, exposing urban students to high quality education available to suburban students, the enjoyment of connecting and interacting with youth and families in one's community. Sally, an Engineer who changed her career to high school teaching states "one of the best parts about teaching is that there is an immediate reward, though the work is challenging, the idea of seeing students transform right before my eyes is well worth it".

Courtney, a Laboratory technician-researcher who changed her career to teaching made the following comment: "Inside the classroom, the biggest issue I face is getting students to care about learning the content. Teaching the content is easy; learning how to handle students that lack intrinsic motivation - that is the hard part."

Despite this, Courtney said "the best part of my job is the daily interaction with students. She mentioned several times how this was much better than being in a lab all day, every day, with the same people. Michael, an award winning teacher who changed his educational path from engineering to teaching mentioned I do not make enough money to just teach. I have not had a contract in 4 years and therefore, have been paid the same rate as a 4 th year teacher with a bachelor's degree - despite the fact that I am an 8th year teacher with a master's degree. But Michael really loves the social interactions that come with being a teacher. He enjoys working with students and knowing that he has made a difference in someone's life. With the help of his civil engineering friends with whom he 
partners, Michael runs an after-school club in Civil Engineering for middle School students. The club has been sponsored by the American Society of Civil Engineers.

\section{Discussion}

Self-determination theory (SDT) (Deci \& Ryan, 1991; Soenens \& Vansteenkiste, 2011) provides a framework for understanding and interpreting the experiences of second career teachers and to identify some of the conditions that foster a successful transition to teaching while providing an understanding of those whose transition was not as successful. When the school administration is autonomy supportive, provides resources to teachers and values what second career teachers have to offer, teachers adjust well to the teaching situation and "love" the work and manifest all the characteristics of powerful intrinsic motivation. In contrast, unsupportive environments which are authoritarian and lacking resources are frustrating to teachers and career changers who then feel devalued and regret the career choice they made.

This research study on the lived experiences is significant for three reasons. First, there is an increase in the number of career changers who join the teaching profession after working in a different career. Second, individuals with education and experience in the STEM subject areas are needed to address the teacher shortage and high teacher turnover in low income high need schools. Third, because of their prior career and life experiences which they bring to bear on their teaching, career change teachers are perceived as a highly competent group who can address the significant needs in STEM teaching.

What are some negatives of being a career/major changer: Larger workload, 78\%"working longer and harder than previous careers" Pay cut resulting in financial difficulties Being treated as an Inexperienced Professional/Staring over in a new profession at the bottom (schools not recognizing content experience as experience) Having less energy to be a First year Teacher due to age and what most second career teachers state: Unrealistic expectations from the school system.

Table 1. Participant demographic information

\begin{tabular}{cccc}
\hline Age & Male & Female & Total \\
\hline $21-30$ & 1 & 2 & 3 \\
$31-50$ & 5 & 6 & 11 \\
$41-50$ & 3 & 1 & 4 \\
\hline
\end{tabular}

\section{Acknowledgements}

This work has been supported by Grant \# 0934809 from the National Science Foundation, The Robert Noyce Scholarship Program. We also thank Joji Thompson for assistance in data collection.

\section{References}

Bauer, C., Thomas, S., \& Sim, C. (2017). Mature age professionals: Factors influencing their decision to make a career change into teaching. Issues in Educational Research, 27(2), 185. https://doi.org/10.1111/0161-4681.00141

Brinkman, S., \& Kvale, S. (2015). Interviews: Learning the Craft of Qualitative Research Interviewing (3rd ed.). Sage Publications.

Deci, E. L., \& Ryan, R. M. (1991). A motivational approach to self. Integration in Personality. In R. Dienstbler (Ed.), Nebraska Symposium on motivation: Perspectives on motivation (Vol. 38, pp. 237-288). Lincoln: University of Nebraska Press.

Dee, T. S., \& Goldhaber, D. (2017). Understanding and addressing teacher shortages in the United States. The Hamilton Project, Brookings Institution.

Feiman-Nemser, S. (2001). From preparation to practice: Designing a continuum to strengthen and sustain teaching.

Grier, J. M., \& Johnston, C. C. (2009). An inquiry into the development of teacher identities in STEM career changers. Journal of Science Teacher Education, 20(1), 57-75. https://doi.org/10.1007/s10972-008-9119-2

Mezirow, J. (1978). Perspective Transformation. Adult Education, 28, 100-110. https://doi.org/10.1177/074171367802800202

Snyder, C., Oliveira, A. W., \& Paska, L. M. (2013). STEM career changers' transformation into science teachers. 
Journal of Science Teacher Education, 24(4), 617-644. https://doi.org/10.1007/s10972-012-9325-9

Soenens, B., \& Vansteenkiste, M. (2011). When is identity congruent with the self? A self-determination theory perspective. In Handbook of identity theory and research (pp. 381-402). Springer, New York, NY. https://doi.org/10.1007/978-1-4419-7988-9_17

Watt, H. M., Richardson, P. W., \& Pietsch, J. (2007). Choosing to teach in the "STEM" disciplines: Characteristics and motivations of science, ICT, and mathematics teachers. Mathematics: Essential research, essential practice, 2, 795-804.

Watters, J. J., \& Diezmann, C. M. (2015). Challenges confronting career-changing beginning teachers: A qualitative study of professional scientists becoming science teachers. Journal of science teacher education, 26(2), 163-192. https://doi.org/10.1007/s10972-014-9413-0

Yin, R. K. (2009). Case study research: Design and methods (4th Ed.). Thousand Oaks, CA: Sage.

Zucker, D. M. (2009). How to do case study research. School of nursing faculty publication series, 2.

\section{Copyrights}

Copyright for this article is retained by the author(s), with first publication rights granted to the journal.

This is an open-access article distributed under the terms and conditions of the Creative Commons Attribution license (http://creativecommons.org/licenses/by/4.0/). 